\title{
Fiscal Deficits and Debt Dimensions of Pakistan
}

\author{
MUHAMMAD ISHFAQ and M. A. CHAUDHARY
}

\section{INTRODUCTION}

Pakistan continues to suffer from a syndrome of high fiscal deficits and severe incidence of debt. Its annual fiscal deficit has stayed constantly at over 6 percent of GDP especially since 1990 [Pakistan (1997-98)]. The prevalence of such a high fiscal deficit over the years in a row has propelled increased borrowing from both internal and external sources to cover the resource gap. With inadequate improvement in the repayment capacity of the country debt has continued to accumulate at a massive rate. Serving as the cause and effect of each other, the volumes of both the fiscal deficit and debt have soared continuously. The most devastating consequence of high fiscal deficit and soaring debt has been the continuous accrual of massive debt-servicing. In fact, both the debt and debt-servicing have reached unaffordable limits. How to alleviate this situation has become the foremost issue of the country. While complete elimination of all the debt and thereby debt-servicing may not be easy to accomplish in the short run, efforts are needed to systematically bring the fiscal deficit down to a minimum affordable limit. What may be the minimum financeable level of fiscal deficit and how it may be reduced to that level are the issues addressed in this paper.

\section{NATIONAL DEBT AND ITS GROWTH}

The occurrence of debt in Pakistan started in 1984-85 when its surplus revenue account turned for the first time into deficit. Subsequently, both the fiscal deficit and debt started to increase at multiple rates. The overall deficit (total revenue minus total expenditures) amounted to Rs 89.2 billion in 1990-91, which swelled by 66 percent to Rs 148 billion in 1997-98. While the domestic component of national debt increased from Rs 448 billion to Rs 1280 billion (185 percent) foreign debt, increased from Rs 272 billion to Rs 697 billion (156 percent) over the same period of time.

As a consequence debt-servicing has increased rapidly from Rs 23 billion to Rs 73 billion (217 percent), during the period between 1990-91 to 1997-98 [Pakistan (199798)]. The deferment of debt-servicing payment started to emerge as a major fiscal

Muhammad Ishfaq is Consultant, World Bank, Islamabad Office. M. A. Chaudhary is Professor of Economics, Quaid-i-Azam University, Islamabad. 
constraint in the early 1990s. With the passage of time, the payment of debt-servicing has become increasingly difficult not only because its amount has been increasing continuously but also because it has been accompanied by a reduction in the availability of low interest bearing external financial assistance and the rising cost of the internal borrowing. Government has been woefully constrained since especially the mid-1990s in reducing its fiscal deficits.

The debt-servicing liability has increased to such an extent that it accounted for 45 percent of the total budget last year. In fact, Pakistan has become so much dependent on external assistance that it seeks foreign loans to defer debt-service payments. Such a dependence on foreign loans has rendered Pakistan unable to withstand the vagaries of the international loan market. This fragile financial and economic situation deprived Pakistan of the resilience to withstand the effects of economic sanctions imposed on it by the USA and other Western countries in May 1998. Although general recession also eroded its economic stability the excessive burden of external and internal debt and poor forex reserves placed Pakistan in a vulnerable situation. Pakistan owed only US \$ 1 million to foreign debtors in 1950-53 but since then it has grown exponentially. In 1980-81, Pakistan borrowed Rs 1 billion net from abroad and with continuous subsequent borrowing its foreign debt rose to Rs 82 billion in 1994-95. The debtservicing has accordingly increased from over Rs 2 billion to Rs 23 billion on foreign debt and from over Rs 3 billion to Rs 83 billion on domestic debt in the same period (Table 1). The available data on loans have shown that gross foreign borrowing had generally exceeded debt-servicing payments on foreign debt and interest payment had exceeded net foreign borrowing in this period as shown in Table 2 . The interest payment on foreign debt as a percentage of GDP increased, as could have been expected, slowly in the beginning and stabilised from the late eighties to nineties at around 1.2 percent (Table 3). However, the amortisation payments on foreign debt have increased from an average of 2.1 percent of GDP during 1980-85 to 3.2 percent in the nineties.

The servicing of the outstanding foreign debt has pre-empted a large proportion of annual growth of GDP and has thus put a severe constraint on national resources, particularly foreign exchange reserves. Consequently, Pakistan has frequently resorted to short-term borrowings at relatively high interest rates and for shorter amortisation periods. Further, the interest rate of foreign borrowing has tended to increase overtime. More specifically, the average rate of interest on foreign debt, which was around 3 percent during the early 1980s, increased to about 4 percent during the early 1990s. Similarly, the amortisation rate on foreign debt also increased from 4.2 percent in 1980 to 6.5 percent in 1995. Both these increases in rates have contributed to the increase in the debt servicing liability, which now constitutes over 40 percent of the country's annual budget and thus accounts for a major burden on the meager resources of the country. The scenario of internal borrowings has been equally unpalatable. Interest payments on them as a percentage of GDP have increased at a significant annual rate of about 10 percent. 
Table 1

National Debt and Its Growth

\begin{tabular}{|c|c|c|c|c|c|c|c|c|c|}
\hline Year & $\begin{array}{c}\text { Foreign } \\
\text { Debt }\end{array}$ & $\begin{array}{c}\text { Domestic } \\
\text { Debt }\end{array}$ & $\begin{array}{c}\text { Net } \\
\text { Foreign } \\
\text { Borrowing }\end{array}$ & $\begin{array}{c}\text { Gross } \\
\text { Foreign } \\
\text { Borrowing }\end{array}$ & $\begin{array}{c}\text { Net } \\
\text { Domestic } \\
\text { Borrowing }\end{array}$ & $\begin{array}{c}\text { Interest } \\
\text { Payments } \\
\text { on } \\
\text { Foreign } \\
\text { Debt }\end{array}$ & $\begin{array}{c}\text { Principle } \\
\text { Payments } \\
\text { on Foreign } \\
\text { Debt }\end{array}$ & $\begin{array}{c}\text { Interest \& } \\
\text { Principle } \\
\text { Payments } \\
\text { on Foreign } \\
\text { Debt }\end{array}$ & $\begin{array}{c}\text { Interest } \\
\text { Payments } \\
\text { on } \\
\text { Domestic } \\
\text { Debt }\end{array}$ \\
\hline $1980-81$ & 82.9 & 58.1 & 1 & 4.4 & 12.9 & 2.3 & 3.4 & 5.7 & 3.3 \\
\hline 1981-82 & 87.2 & 74.6 & 4.3 & 7.1 & 16.5 & 2 & 2.9 & 4.9 & 5.2 \\
\hline $1982-83$ & 118.3 & 95.8 & 31.1 & 36.1 & 21.2 & 3.1 & 0.5 & 8.1 & 7.5 \\
\hline $1983-84$ & 127.7 & 123.1 & 9.4 & 15.5 & 27.3 & 3.7 & 6.1 & 9.8 & 10.4 \\
\hline $1984-85$ & 147.5 & 158.1 & 19.8 & 27.5 & 35 & 3.8 & 7.8 & 11.5 & 12.8 \\
\hline $1985-86$ & 179.3 & 203.1 & 31.8 & 41.6 & 45 & 4.9 & 9.7 & 14.6 & 14.8 \\
\hline 1986-87 & 206.5 & 248.5 & 27.3 & 39.7 & 45.5 & 6.5 & 12.4 & 18.9 & 17 \\
\hline $1987-88$ & 227.3 & 290.1 & 20.7 & 32.9 & 41.6 & 7.5 & 12.2 & 19.7 & 24.8 \\
\hline 1988-89 & 272.7 & 333.2 & 45.5 & 58.6 & 43.1 & 8.5 & 13.2 & 21.6 & 30.7 \\
\hline $1989-90$ & 323.7 & 381.3 & 51 & 66.9 & 48.1 & 10.5 & 15.9 & 26.4 & 38 \\
\hline 1990-91 & 346.9 & 484.2 & 23.2 & 40.8 & 66.9 & 12 & 17.5 & 29.5 & 38 \\
\hline $1991-92$ & 431.3 & 525.1 & 84.4 & 107.3 & 76.9 & 14.7 & 22.9 & 37.6 & 52.8 \\
\hline 1992-93 & 494.4 & 608 & 36.1 & 89 & 83 & 16.8 & 25.9 & 42.8 & 65.1 \\
\hline $1993-94$ & 613 & 702 & 118.6 & 151.1 & 94 & 20.1 & 32.5 & 52.7 & 81 \\
\hline $1994-95$ & 682.3 & 784 & 69.4 & 109.3 & 82 & 23.1 & 39.9 & 63 & 82.7 \\
\hline Average (1980-95) & 513.6 & 613.5 & 71.7 & 99.5 & 80.5 & 17.3 & 27.8 & 45.1 & 63.9 \\
\hline
\end{tabular}


Table 2

Debt, Borrowing and Debt Servicing as \% of GDP

\begin{tabular}{|c|c|c|c|c|c|c|c|c|c|}
\hline Year & $\begin{array}{c}\text { Foreign } \\
\text { Debt }\end{array}$ & $\begin{array}{c}\text { Domestic } \\
\text { Debt }\end{array}$ & $\begin{array}{c}\text { Net } \\
\text { Foreign } \\
\text { Borrowing }\end{array}$ & $\begin{array}{c}\text { Gross } \\
\text { Foreign } \\
\text { Borrowing }\end{array}$ & $\begin{array}{c}\text { Net } \\
\text { Domestic } \\
\text { Borrowing }\end{array}$ & $\begin{array}{c}\text { Interest } \\
\text { Payments } \\
\text { on Foreign } \\
\text { Debt }\end{array}$ & $\begin{array}{c}\text { Principle } \\
\text { Payments } \\
\text { on Foreign } \\
\text { Debt }\end{array}$ & $\begin{array}{c}\text { Interest \& } \\
\text { Principle } \\
\text { Payments } \\
\text { on Foreign } \\
\text { Debt }\end{array}$ & $\begin{array}{c}\text { Interest } \\
\text { Payments } \\
\text { on } \\
\text { Domestic } \\
\text { Debt }\end{array}$ \\
\hline $1980-81$ & 29.8 & 20.9 & 0.4 & 1.6 & 4.6 & 0.8 & 1.2 & 2 & 1.2 \\
\hline $1981-82$ & 26.9 & 23 & 1.3 & 2.2 & 5.1 & 0.6 & 0.9 & 1.5 & 1.6 \\
\hline $1982-83$ & 32.5 & 26.3 & 8.5 & 9.9 & 5.8 & 0.9 & 1.4 & 2.2 & 2.1 \\
\hline $1983-84$ & 30.4 & 29.3 & 2.2 & 3.7 & 6.5 & 0.9 & 1.5 & 2.3 & 2.5 \\
\hline 1984-85 & 31.2 & 33.5 & 4.2 & 5.8 & 7.4 & 0.8 & 1.6 & 2.4 & 2.7 \\
\hline $1985-86$ & 34.8 & 39.5 & 6.2 & 8.1 & 8.7 & 0.9 & 1.9 & 2.8 & 2.9 \\
\hline 1986-87 & 36.1 & 43.4 & 4.8 & 6.9 & 7.9 & 1.1 & 2.2 & 3.3 & 3.1 \\
\hline 1987-88 & 33.6 & 43 & 3.1 & 4.9 & 6.2 & 1.1 & 1.8 & 2.9 & 3.7 \\
\hline 1988-89 & 35.4 & 43.3 & 5.9 & 7.6 & 5.6 & 1.1 & 1.7 & 2.8 & 4 \\
\hline 1989-90 & 37.8 & 44.5 & 6 & 7.8 & 5.6 & 1.2 & 1.9 & 3.1 & 4.4 \\
\hline $1990-91$ & 34 & 43.9 & 2.3 & 4 & 6.6 & 1.2 & 1.7 & 2.9 & 3.7 \\
\hline $1991-92$ & 35.6 & 43.3 & 7 & 8.9 & 6.3 & 1.2 & 1.9 & 3.1 & 4.4 \\
\hline 1992-93 & 36.8 & 45.3 & 4.7 & 8.6 & 6.2 & 1.3 & 1.9 & 3.2 & 4.9 \\
\hline $1993-94$ & 39 & 44.6 & 7.5 & 6.6 & 6 & 1.3 & 2.1 & 3.3 & 5.2 \\
\hline 1994-95 & 36.6 & 42 & 3.7 & 9.6 & 4.4 & 1.2 & 2.1 & 3.4 & 4.4 \\
\hline Growth Rate & 1.5 & 5.1 & 18.1 & 9.8 & -0.4 & 2.9 & 4.1 & 3.6 & 9.8 \\
\hline
\end{tabular}

Source: Pakistan (Various Issues). 
Table 3

Terms of Foreign and Domestic Loans

\begin{tabular}{|c|c|c|c|c|c|}
\hline Year & $\begin{array}{c}\text { Interest } \\
\text { Rate on } \\
\text { Foreign } \\
\text { Debt }\end{array}$ & $\begin{array}{c}\text { Amortisation } \\
\text { on Foreign } \\
\text { Debt }\end{array}$ & $\begin{array}{c}\text { Debt } \\
\text { Servicing } \\
\text { Rate on } \\
\text { Foreign } \\
\text { Debt }\end{array}$ & $\begin{array}{l}\text { Amortisa- } \\
\text { tion Period } \\
\text { of Gross } \\
\text { Foreign } \\
\text { Borrowing }\end{array}$ & $\begin{array}{c}\text { Interest } \\
\text { Rate on } \\
\text { Domestic } \\
\text { Debt }\end{array}$ \\
\hline 1980-81 & 2.8 & 4.2 & 7 & 29.3 & 7.4 \\
\hline 1981-82 & 2.4 & 3.4 & 5.9 & 28 & 9 \\
\hline 1982-83 & 3.6 & 5.7 & 9.2 & 27.8 & 10.1 \\
\hline 1983-84 & 3.1 & 5.2 & 8.3 & 26.5 & 10.9 \\
\hline 1984-85 & 2.9 & 6.1 & 9 & 24.9 & 10.4 \\
\hline 1985-86 & 3.3 & 6.6 & 9.9 & 23.4 & 9.4 \\
\hline 1986-87 & 3.6 & 6.9 & 10.6 & 26.2 & 8.7 \\
\hline 1987-88 & 3.6 & 5.9 & 9.5 & 26.3 & 10 \\
\hline 1988-89 & 3.7 & 5.8 & 9.5 & 22.7 & 10.6 \\
\hline 1989-90 & 3.9 & 5.8 & 9.7 & 20.1 & 11.4 \\
\hline 1990-91 & 3.7 & 5.4 & 9.1 & 23.4 & 10 \\
\hline 1991-92 & 4.2 & 6.6 & 10.8 & 20.2 & 11.8 \\
\hline 1992-93 & 3.9 & 6 & 9.9 & 25.2 & 12.4 \\
\hline 1993-94 & 4.1 & 6.6 & 10.7 & 24.7 & 13.3 \\
\hline 1994-95 & 3.8 & 6.5 & 10.3 & 20.8 & 11.8 \\
\hline Growth Rate & 3.9 & 6.3 & 10.2 & 22.7 & 12 \\
\hline
\end{tabular}

Source: Pakistan (Various Issues).

\section{TREND IN FISCAL DEFICIT}

The annual budget deficit in Pakistan has ranged continuously around 5 percent of GDP since 1980-81. It peaked at almost 9 percent of GDP in 1990-91. It was, however, subsequently managed down to 5.5 percent by 1994-95. Until the mid-80s, the contribution of the primary budget deficit i.e. overall budget deficit net of interest payments, was larger than interest payments and now, not only the reverse holds, but the interest payments also claim the major share in the budget deficit. While the former has reduced from over 3 percent of GDP in the 80s to less than 2 percent in the 90s, interest payments have risen from 2 percent of GDP in 1980-81 to almost 5.5 percent by 1994-96 (Table 4). Large fiscal deficits have considerable adverse implications for macroeconomic balances. The available research evidence shows that large fiscal deficits on the one hand push up the inflation and interest rates, and discourage saving and private investment, on the other. Empirical research on this issue has established the existence of a strong positive correlation between fiscal deficits and current account deficits. In fact, fiscal deficit has econometrically been found as the significant determinant of the variations in the current account deficit of Pakistan [Ahmed (1996)]. 
Table 4

Summary of Fiscal Deficits

\begin{tabular}{|c|c|c|c|c|c|}
\hline Year & $\begin{array}{l}\text { Overall } \\
\text { Deficit }\end{array}$ & $\begin{array}{c}\text { Deficit as } \\
\% \text { of GDP } \\
\text { (mp) }\end{array}$ & $\begin{array}{c}\text { External } \\
\text { Financing }\end{array}$ & $\begin{array}{l}\text { Internal } \\
\text { Financing } \\
\text { (Banking) }\end{array}$ & $\begin{array}{c}\text { Internal } \\
\text { Financing } \\
\text { (Non- } \\
\text { Banking) }\end{array}$ \\
\hline $1985-86$ & 36.77 & 7.6 & 5.16 & 12.87 & 18.73 \\
\hline 1986-87 & 72.01 & 8.2 & 8.18 & 27.73 & 6.09 \\
\hline 1987-88 & 46.55 & 8.5 & 15.30 & 26.48 & 4.77 \\
\hline 1988-89 & 56.87 & 7.4 & 12.69 & 30.93 & 13.94 \\
\hline 1989-90 & 56.05 & 6.5 & 18.19 & 37.86 & 0.82 \\
\hline 1990-91 & 89.19 & 8.7 & 22.94 & 29.58 & 3.53 \\
\hline 1991-92 & 89.97 & 7.4 & 18.02 & 72.46 & 0.51 \\
\hline 1992-93 & 107.52 & 8.0 & 24.33 & 63.21 & 19.97 \\
\hline 1993-94 & 92.17 & 5.9 & 24.62 & 12.50 & 55.04 \\
\hline 1994-95 & 105.35 & 5.6 & 29.31 & 26.11 & 49.92 \\
\hline 1995-96 & 137.83 & 6.3 & 28.58 & 52.27 & 56.98 \\
\hline 1996-97 & 156.01 & 6.3 & 27.63 & 71.87 & 56.49 \\
\hline 1997-98 & 143.22 & 4.6 & 14.71 & 39.20 & 89.30 \\
\hline
\end{tabular}

Source: Pakistan (Various Issues).

\section{ANALYTICAL MODEL}

Historically, Pakistan has, despite high fiscal deficits, experienced low rates of inflation compared to many other developing countries. This is paradoxical, as high fiscal deficits have usually been associated with rising inflation owing to seinorage. Why the relationship between fiscal deficits and inflation in Pakistan has not been as pronounced as in some Latin American countries ${ }^{1}$ has been attributed by Haque and Montiel (1992) to relatively cheap external and domestic financing and continuous debt rescheduling which together operated to avoid hyperinflation. It was also because some of the government debt was held by financial institutions to satisfy liquidity requirements. Until some years ago, the Government of Pakistan was engaged in financial repression, which rendered the domestic banks unable to lend at the open market rates. At the same time, the State Bank of Pakistan forced commercial banks to allocate 30 percent of their portfolio in the form of government securities and cash to meet its reserve requirements. The interest rates paid on domestic and foreign debt were much below international interest rates during the seventies and eighties as measured by LIBOR. $^{2}$ The grant element implicit in this concessional lending available to the

\footnotetext{
${ }^{1}$ See for Example Pasha and Aisha, "Pakistan in the 'Debt-Trap' can we stand”.
}

${ }^{2}$ London Inter Bank Offer Rate (LIBOR). 
government during this period was regarded as a source of revenue rather than financing. Such an explanation could provide only a partial explanation for the coexistence of high fiscal deficits and low inflation. Further, Haque and Montiel (1992) suggested that Pakistan's high growth rates induced expansion in seinorage and bases of conventional taxes, which, in turn, enabled the sustenance of high deficits. Thus, can we believe that the prevailing fiscal deficits, ordinarily being higher than sustainable, are still manageable? To answer this question, we need to examine the dynamics and relationships of fiscal deficit with total government debt and money creation. The relationship may be expressed as below:

$$
B_{t} / Y_{t}-\left[B_{(t-1)} / Y_{(t-1)}\right]=\left[(r-g) * B_{t} / Y_{t}\right]+\left[\left(G_{t}-T_{t}\right) / Y_{t}\right] \quad \ldots \quad \ldots
$$

Equation 1 is derived as:

$$
\text { Let } b^{*}=B^{*} / P^{*} e / y
$$

Where $e=E \cdot p^{*} / P$

$$
\Delta b^{*}=(r-g)^{*} \cdot b^{*}-v+(\Delta e / e)^{*}
$$

where $b^{*}$ is external debt to output ratio, $e$ is real exchange rate, $B^{*}$ is the dollar value of foreign debt, $P^{*}$ foreign price level, $Y$ is GDP, $B$ the total debt, $y$ is real output, $r$ the real interest rate on external debt, $(G-T)$ the budget deficit and $g$ the real rate of economic growth.

If we assume that government finances the budget deficit through monetisation i.e.,

$$
P^{*} B D=B f+B P=H+B P
$$

$P^{*}$ foreign price level in US dollars. $H$ is the monetary base and $B P$ the current account deficit/surplus. Then Equation (1) can be written as:

$$
B_{t} / Y_{t}-\left[B_{(t-1)} / Y_{(t-1)}\right]=\left[(r-g) * B_{t} / Y_{t}\right]+\left[\left(G_{t}-T_{t}\right) / Y_{t}\right]+H
$$

Assuming $B_{t} / Y_{t}-B_{(t-1)} / Y_{(t-1)}=b$ and $b$ which is the change in total debt to GDP ratio in itself may be expressed in the form of the following equation:

$$
b=\left[(r-g) * B_{t} / Y_{t}\right]+\left(G_{t}-T_{t}\right) / Y_{t}+H \quad \ldots \quad \ldots \quad \ldots
$$

Equation (2) provides that the change in government debt as a percentage of GDP can be explained by three components. The expression $\left.\left[(r-g) * B_{t} / Y_{t}\right)\right]$ shows the dynamics of the debt caused by the interaction of real interest rate and real economic growth rate with each other. Given that the government is running a primary deficit, it will need to borrow from both internal and external debtors to bridge the gap. Assuming further that if the real interest rate on this borrowing exceeds the real growth rate of GDP, then the numerator of debt/GDP ratio will grow faster than the denominator, causing this ratio to grow continuously and indefinitely. This diminishes the government's ability to borrow 
any further because it will affect its credibility adversely in the international financial markets. At the same time, the possibility of financing primary deficit through money creation is ruled out for reasons of seinorage inducing inflationary effects in the economy [Burney (1998)].

\section{FISCAL CONSISTENCY FRAMEWORK}

Following the standard procedure, the government budget constraint can be expressed as:

$$
D+i B+I_{f}\left(B_{f}-N F A_{f}\right) E=B+\left(\begin{array}{lll}
\left.B_{f}-N F A_{f}\right) E+M \quad \ldots
\end{array}\right.
$$

Where $D$ is non-interest deficit in local currency, $I$ nominal domestic interest rate, $B$ domestic debt in local currency, $I_{f}=$ nominal foreign interest rate, $B_{f}$ foreign debt in dollars, $N F A_{f}$ net foreign assets in dollars, $E$ exchange rate (local currency/dollars), $M$ nominal money stock.

It has been argued by Haque and Montiel (1992) that the deficit should be defined to include not only the control of government's budget deficit but also the budget deficits of the local governments and public enterprises as well as the profit and loss accounts of the central bank. Similarly, they further proposed that the capital gains and losses due to exchange rate and inflation charges should also be included in the analysis. However, we are constrained by the non-availability of reliable data in adequate quantity to incorporate the budget deficits of local government and the profit and loss of the central bank. We therefore restrict our focus entirely on formulating a model solely with government budget in view [Tanzi (1988)].

With these limitations in view, we can express Equation (3) in real terms as:

$d+r b+r_{f}\left(b_{f}-N F A_{f}\right) e=b+\left(b_{f}-N F A_{f}\right) e+(D M / P) \quad \ldots \quad \ldots$

Lower case letters denote real variables and $r$ is defined as:

$r=(I+1)(I+\pi)-1 \quad$ where $\pi$ is the inflation rate.

In compliance with the fact that $(M / p)=D m+m \pi$ and $m=M / p$ (real money balances),

Equation (4) may be written as:

$D+r b+r_{f}\left(b_{f}-N F A_{f}\right) e=b+\left(b_{f}-N F A_{f}\right) e+m+m \pi \ldots \quad \ldots$

Its left-hand-side gives fiscal deficit in real terms. Its right-hand-side, on the other hand, explains that a real deficit can be financed through changes in real values of domestic and foreign debts plus the revenue which is generated through the monetisation of debt. This revenue is in the form of inflation tax $(m \pi)$ and seinorage revenue $(\mathrm{m})$.

If we assume that government adopts a strategy to keep a constant debt/GDP ratio which implies that real domestic debt cannot grow faster than the real output and real net 
foreign debt cannot grow faster than the output/exchange rate then the following expression is obtained:

$$
b=g b \text { and } \quad\left(b_{f}-N F A_{f}\right) e^{\prime}=\left(b_{f}-N F A_{f}\right)\left(g-e^{\prime}\right) \quad \ldots \quad \ldots
$$

where $g=$ GDP growth rate and $e^{\prime}$ is the percentage change in the real exchange rate. By introducing these constraints into Equation (5), we obtain:

$$
d+r b+r_{f}\left(b_{f}-N F A_{f}\right) e=g b+\left(b_{f}-N F A_{f}\right)\left(g=e^{\prime}\right)+g m+m \pi
$$

From Equation (7), we can calculate the financeable deficits consistent with the target growth rate of the economy and inflation. The model has been estimated for the period 1980 to 1998 by assuming a GDP growth of 5.5 percent and exchange rate depreciation and inflation of 10 percent each. The financeable deficits are calculated on the basis of different macroeconomic targets for the nineties under three scenarios: optimistic, normal and pessimistic. The financeable deficit under the optimistic scenario is calculated by assuming high growth rate of 7 percent and an inflation rate of 5 percent. However, the normal target is based on the growth rate at 5.5 percent and inflation rate of 10 percent. Finally, the pessimistic target incorporates a low growth rate of 3.5 percent and an inflation rate of 20 percent. In calculating all these scenarios, an exchange rate depreciation of 10 percent per annum is assumed.

\section{DISCUSSION OF RESULTS}

Applying the analytical model to Pakistan's situation, it is observed that Pakistan ran large budget deficits between 1973 to 1981 . By implication, the associated high primary deficits alone would have added considerably to the total debt-GDP ratio. However, the deficit-induced addition to the debt-GDP ratio could not occur mainly because the effect of these deficits was more than offset by opposite effects of a combination of revenues from seinorage, negative interest rates, rapid economic growth and appreciation of real exchange rate. However, for the later period from 1981 to 1995 (as given in Table 2), the debt-GDP ratio grew at a much faster rate than for the earlier periods. It appears that if the debt-GDP ratio is not maintained and unless corrective measures are taken, the primary budget deficit in absolute terms is expected to rise annually at about 18 percent, net external borrowing at around 15 percent and internal borrowing at 16 percent. As such, Pakistan's external debt position in the absence of preventive policies is expected to become worse in the future and the position of the internal debt is not likely to improve either. Consequently, the budget of servicing the external debt will rise to more than 9 percent of GDP and budget deficit as percentage of GDP will rise beyond tolerable limits (Table 5).

It is the fiscal deficit that sets the basis of determining government's loan requirements. It also serves as an important determinant of the inflation rate. In fact, the level of fiscal deficit is related directly to the requirements of external assistance and the 
rate of inflation. High fiscal deficits create higher loan requirements and contribute positively to the prevailing rate of inflation. The government under many circumstances may be tempted to go for high fiscal deficits. However, since high fiscal deficits are fraught with unfavourable consequences, determining and keeping fiscal deficit within tolerable limits becomes imperative. It is to this end that this paper has calculated the level of fiscal deficits under different scenarios based on relevant macro variables. The results of the analysis are depicted in Table 5 below:

Table 5

Levels of Financeable Fiscal Deficits Estimated for Pakistan

\begin{tabular}{lll}
\hline Target & \multicolumn{1}{c}{ Assumptions } & Average Financeable Deficit (AFD) \\
\hline Optimistic & GDP Growth $=7 \%$ rate & AFD as percentage of GDP $=4.94$ \\
& Inflation Rate $=5 \%$ & \\
Normal & GDP growth rate $=5.5 \%$ & AFD as percentage of GDP $=3.70$ \\
& Inflation Rate $=10 \%$ & AFD as percentage of GDP $=2.87$ \\
Pessimistic & GDP growth rate $=4.5 \%$ & \\
& Inflation Rate $=1.5 \%$ &
\end{tabular}

This table reveals that the average fiscal deficits for the nineties have been calculated at around 6.5 percent of GDP. This level of fiscal deficit has been regarded high by all the concerned quarters. In the past, pressures have frequently been mounted to bring its level down. If fiscal consistency is to be achieved in terms of meeting the target inflation and growth rate and keeping the debt to output ratio constant, our analysis suggests that Pakistan needs to reduce its fiscal deficit to the range of 2.87 per cent of GDP if the pessimistic scenario is to be pursued, to 4.94 percent of GDP if the optimistic scenario is the priority. If these reductions in actual fiscal deficits are not met, then our consistency framework implies that this would involve adjustments either in terms of increasing the inflation rate, or sacrificing the GDP growth rate or giving up the policy of keeping constant debt/GDP ratio.

It may be realised that in the presence of high budget deficit, Pakistan finds itself in a debt-trap. The high level of outstanding debt implies high interest payments which affect the budget deficit in a one-to-one manner. Consequently, the budget deficit which has inevitably to be financed by borrowing becomes susceptible to explosive growth and thereby to more debt. This, in turn, creates fundamental macroeconomic imbalances in the country. Any government would wish to reduce the fiscal deficits to a low sustainable level so that it can achieve its macroeconomic targets in terms of GDP growth, low sustainable inflation and a debt-free economy. This, unfortunately, has become an uphill task over the years. It requires a concrete plan of actions based on tough decisions, though politically unpalatable and socially unpopular, which can be implemented only with strong political will and sincerity of purpose. It has been 
ascertained that unless the fiscal deficit is kept under control, it would not ordinarily be possible to escape the consequences of rising inflation and debt-servicing. The level of total debt is already in the ratio of 94 to 100 of GDP. If it continues to increase at the rate experienced in the immediate past, and no effective and efficacious measures seem to have been taken so far to keep it from increasing, it will soon exceed the GDP. Similarly, the debt-servicing is currently accounting for 45 percent of the national budget, which is already in excess of what the nation allocates for its defence requirements that the regional situation demands. Such a high requirement of debtserving impinges very severely on the development allocations. To tackle the problem of excessive debt-servicing, there is a need to identify the forces and factors which operate to its accrual.

The analysis reveals that the basic cause of high inflation and debt-serving is the fiscal deficits in the country. The fiscal deficits, in turn, have become a regular phenomenon due to insufficient revenue generation and allocation of a large share of whatever financial resources are generated to finance non-development expenditure and unproductive projects. The subdued increase in expansion of domestic financial resource also stems from the tax system which is not delivering. There is a great need to reform the tax system by way of improving its collection efficiency modification of the payment rates, recovery of accumulated dues with individuals and agencies and, above all, enlargement of the tax net. Further, the government may disband highly indebted public enterprises or privatise them to use their sales proceeds for settlement of some outstanding debt obligations and reduce its own scope of interference in many sectors [Kemal (1992)].

It may be concluded on the basis of the analysis and the discussion that the best policy is to increase additional financial resources from within the economy so that the need of deficit financing is reduced leading ultimately to reduced pressure of borrowing, especially from foreign lenders. If the pressure of borrowing is reduced, then the need of incurring financial deficits can accordingly be reduced. Simultaneously, efforts must be made to increase the growth rate of the economy which is perhaps the panacea for alleviation of dependence on foreign financial assistance. Attention need also to be paid to increase the output of high value-added and high quality products for exports to ease the chronic shortage of foreign exchange.

\section{SUMMARY AND CONCLUSION}

This paper has mathematically analysed the fiscal deficit and debt of Pakistan. It has been found that a prolonged prevalence of high deficits has caused the accumulation of huge debt accompanied by the accrual of excessive burden of debt servicing. It appears that the fiscal deficit and debt have served as the cause and effect of each other. As such, the current burden of debt servicing has risen and is now severely straining the economy by pre-empting a large share of annual increase in GDP growth. The analysis, based on the period from 1980-81 to 1997-98, shows that unless the effective corrective 
measures are put in place the primary budget deficit in absolute terms is likely to rise annually at about 18 percent. To meet the resource gap requirements created by such a high compound growth rate of deficit, the needed net external and internal borrowings are likely to increase respectively at 16 and 18 percent per annum. Debt and debtservicing alleviation requires the fiscal deficit to be managed to some low level. Using a simple model, we have estimated the average deficit level that the economy can finance without straining itself under three different growth rates of GDP and inflation. The average financeable fiscal deficit has been found to be reducible to around 3 percent of GDP by achieving GDP growth rate of just about 6 percent and inflation rate under 10 percent. To achieve it, there is need to increase domestic financial resources by increasing the rate of growth of the economy, reforming the present tax system by way of its efficiency, coverage and mode of tax payment and, above all, by increasing the production of high value added products with export potential with a view to reducing the current high dependence on large imports of varied commodities.

A number of additional aspects of fiscal deficit and debt may be explored further. One promising aspect is the simultaneous determination of the balance of payment deficit, overall fiscal deficit, debt and their further projection.

\section{REFERENCES}

Ahmad, E. (1996) Capital Inflows and National Debt. The Pakistan Development Review 35:4 943-960.

Burney, N. (1998) Determinants of Debt Problem in Pakistan and its Debt Servicing Capacity. The Pakistan Development Review 27:4.

Cassen, R. A., Cuncan, S. Guisinger, E. Hooper, and O. Noman (1990) The Effectiveness of Aid to Pakistan. Islamabad: Economic Affairs Division and UNDP.

Haque, Nadeem U., and Peter J. Montiel (1992) Fiscal Policy Choices and Macroeconomic Performance in the Nineties. Financing Pakistan's Development in the 1990's. Karachi: Oxford University Press.

Kemal, A. R. (1992) Self Reliance and Implication for Growth and Resource Mobilisation. The Pakistan Development Review 32:4 1157-1167.

Pakistan, Government of (Various Issues) Economic Survey. Finance Division, Islamabad.

Pasha, H. A., and Aisha G. P. (1999) Pakistan in the Debt-Trap. Can we Stand? The News July.

Tanzi, V., M. I. Blejer, and M. O. Teijeiro (1988) The Effects of Inflation on the Measurement of Fiscal Deficits. In M. I. Blejer and C. Ke-Young (eds) Measurement of Fiscal Impact: Methodological Issues. International Monetary Fund, Washington, D. C. (Occasional Paper 59.)

White, H. (1992) The Macroeconomic Impact of development Aid: A Critical Survey. Journal Of Development Studies 28: 163-240. 


\section{Comments}

In the wake of ever-increasing debt burden, fiscal deficit and its impact on external and internal borrowing have acquired tremendous economic and political significance in Pakistan. In this backdrop, a study of fiscal deficit, and the debt dimensions of Pakistan is bound to arouse interest among economists and policymakers of the country. Leaving aside some typographical errors, which I am sure the authors will take care of before submitting the final draft, I will confine my comments to the substance of the paper. Most of my comments are in the form of questions and queries.

1. After presenting their model with the help of seven equations, the authors tell us that "the model has been estimated for the period 1980 to 1998 by assuming a GDP growth of 5.5 percent and exchange rate depreciation and inflation of 10 percent each". Several questions come to mind.

(i) What was the method of estimation?

(ii) What estimation results were obtained?

(iii) Why would one estimate the model for the period 1980 to 1998 by assuming certain values for GDP growth, exchange rate depreciation, and inflation when actual figures are readily available for this period?

2. The model presented in the paper assumes the budget deficit (G-T) to be exogenous. It is a well known fact that both government expenditure $G$ and revenues $\mathrm{T}$ depend on a number of factors. The dependence of tax revenues on national income is well established in the literature on public finance. Therefore treating $G$ and $T$ as endogenous variables would lead to interesting policy implications about national debt. It might also modify some of the conclusions of the paper.

A clearer exposition would also have helped in making the paper readerfriendly. For example, the assumption of a constant debt-GDP ratio used to derive Equation 6 of the model needs further elaboration because in the real world of Pakistan's economy, debt has grown much faster than GDP, causing debt-GDP ratio to increase.

The paper treats debt requirements of the economy as a single gap between government revenues and expenditure. In fact two other gaps can also be identified that determine total debt requirements of a country, namely, the gap between private saving and investment, and the gap between exports and imports. Admittedly, incorporating all these gaps into the present model would be an ambitious exercise. 
This, however, indicates a possible avenue for future research to which the authors have alluded.

It is a noteworthy fact that the economists had started ringing alarm bells about the possibility of debt explosion as early as in the mid-sixties. The authors deserve commendation for keeping up this tradition of analysing various scenarios of national debt and informing us about what needs to be done to make this burden manageable.

Pakistan Institute of Development Economics,

Najam us Saqib

Islamabad. 